„Analiza i Egzystencja” 47 (2019)

ISSN 1734-9923

DOI: $10.18276 /$ aie.2019.47-02

\title{
SILVER BRONZO*
}

\section{TRUTH-BEARERS IN FREGE AND THE TRACTATUS}

Keywords: Frege, Wittgenstein, Tractatus Logico-Philosophicus, truth-bearers, propositions, thoughts, truth

\section{Introduction}

What is it that is true or false in a primitive, non-derivate way? According to Frege, early Russell, and much of subsequent analytic philosophy, the primary truth-bearers are mind-independent entities. Mental or linguistic acts, such as judgments and assertions, can be said to be true or false - if at all - only in a derivative sense. In recent years, this entity-based approach has been challenged. Some have proposed act-theoretic accounts identifying

* Silver Bronzo - Assistant Professor of Philosophy at the National Research University Higher School of Economics, Moscow. He received his PhD in 2015 from the University of Chicago and has published several articles and book chapters in the history of analytic philosophy and the philosophy of language.

Address for correspondence: National Research University Higher School of Economics, School of Philosophy, Staraya Basmannaya Ulitsa 21/4, Moscow, 105066 Russia. E-mail: silver.bronzo@gmail.com. 
the primary truth-bearers with concrete mental or linguistic acts. ${ }^{1}$ Others have proposed accounts that are not act-theoretic, because they deny that acts are true or false, but are nonetheless act-based, because they hold that the primary truth-bearers essentially involve concrete acts. In particular, some have argued that the primary truth-bearers are the "products" of mental or linguistic acts. ${ }^{2}$ I am going to argue that Wittgenstein's Tractatus proposes an act-based account and is in this respect deeply opposed to Frege. For the Tractatus, the primary bearers of truth and falsity are facts-in-use. These essentially involve concrete acts, namely acts of using mental or linguistic facts in a certain way. I shall leave open the question of whether the Tractatus' account is not only act-based, but also act-theoretic. This depends on whether a fact-in-use (i.e., a fact used on a certain occasion in a certain way) is the same as the use of a fact (i.e., the concrete act of using a fact in a certain way) - a question that I shall not attempt to answer. ${ }^{3}$

\section{Three platitudes}

I am going to contrast the Tractarian account of truth-bearers with Frege's by looking at how they deal with three platitudes that are widely believed to place constraints on any adequate view of the matter. ${ }^{4}$

First, what I shall call Repeatability. One can say or think the same thing on different occasions. Suppose I say, now, that 2 plus 2 equals 4 . This is a particular, historical event. But I can say the same thing again - here I go: 2 plus 2 equals 4 . I just performed two distinct historical acts of saying,

1 See Jubien (2001), Moltmann (2003), Soames (2010a, 2010b, 2015), Hanks (2007, $2011,2015)$. For a discussion of this approach in relation to its historical sources and predecessors (including Russell's Multiple Relation Theory of Judgment and Husserl's theory of propositional contents as “species"), see Moltmann \& Textor (2017), pp. vii-xviii.

2 See Moltmann (2014, 2017), drawing on Twardowski (1912).

3 During the last round of revisions of this essay, I found out that Soames (2016) makes similar points about the Tractatus. Soames goes further than I do in arguing that the Tractarian distinction between a fact and a fact-in-use is untenable (because the two phrases "pick out [the same] entity" and a fact-in-use is a "pseudo-entity", pp. 8, 16) and should be replaced with a distinction between a fact and the use of a fact, which would render the Tractarian account of truth-bearers fully act-theoretic and not merely act-based.

4 The following presentation of the three platitudes draws on Bell (1987) and Ryle (1930). 
but I said the same thing. Secondly, what I shall call Shareability. Different persons can say or think the same thing. Suppose I say, again, that 2 plus 2 equals 4. You can say the same thing. My act and your act are different historical events, but they amount to the saying of the same thing. Third, what I shall call Objectivity. What we say or think may be true independently of the fact that anybody has ever said or thought it. If I say that 2 plus 2 equals 4, I say something true; but what I say would have been true even if I had never said or thought it. It was true before humankind even existed, and will continue to be true when humankind becomes extinct and there is no one left in the universe to think or say anything at all.

Let's see how the theory that emerges from a major strand in Frege's mature writings - including Der Gedanke - purports to vindicate these platitudes. For the sake of brevity, I will refer to it simply as "Frege's theory", even though, as we shall see below, there are aspects of Frege's philosophy to pull in a different direction.

\section{Frege's theory}

Shortly after the beginning of Der Gedanke, Frege sets out to "delimit [...] the region within which truth can be predicated, the region in which there is any question of truth" (1918, p. 59/326). His answer is that "the only thing that raises the question of truth at all" is a Gedanke, a "thought" (p. 60/327). Thoughts are expressed by sentences and constitute their senses (p. 61/328); they are grasped in acts of thinking (p. 62/329); and are acknowledged as true in acts of judgment (p. 62/329). They are abstract, mind-independent entities inhabiting a "third realm" (p. 69/337) distinct both from the "outer" and the "inner world" (p. 66/334). The outer world is the realm of what can be perceived by the senses, i.e., physical objects such as "trees, stones, and houses". The inner world is the realm of "ideas", i.e., mental items that always belong to the content of someone's consciousness and include "sense impressions", "creations of this imagination", "sensations", "feelings", "moods", "inclinations" and "wishes" (p. 67/334).

Thoughts are in some respects like physical objects and unlike ideas; in some respects like ideas and unlike physical objects; and in some respects unlike both. They share with physical objects the fact that they are 
mind-independent. Thoughts may exist and be true even though nobody thinks them: ${ }^{5}$

[T]he thought we have expressed in the Pythagorean theorem is timelessly true, true independently of whether anyone takes it to be true. It needs no owner. It is not true only from the time when it is discovered; just as a planet, even before anyone saw it, was in interaction with other planets.

(Frege, 1918, p. 69/337)

In order to be true, thoughts - e.g. laws of nature - not only do not need to be recognized by us as true: they do not have to have been thought by us at all. A law of nature is not invented by us, but discovered, just as a desolate island in the Arctic Ocean was there long before anyone set eyes on it.

(Frege, 1897, p. 144/233)

The mind-independence of thoughts sets them apart from ideas, which always need an owner. An idea is always the idea of someone who has it; they don't "go around the world without an owner, independently" (1918, p. 67/334). However, thoughts share with ideas the fact that they are not sensibly perceptible. Ideas cannot be seen or perceived, they can only be had. For example, one sees a tree, but has the visual impression of a tree (p. 67/334). Similarly, a thought "is in itself imperceptible by the senses" and becomes sensibly perceptible only in so far as it "gets clothed in the perceptible garb of a sentence" (p. 61/328). Finally, thoughts differ both from physical objects and ideas because they do not belong to the temporal and causal order. Both physical and mental objects are subject to change as a result of changes in other physical or mental objects. For example, a light ray may strike the visual nerve and give rise to an idea of a tree, which may interact with other ideas and lead to a decision, which may in turn lead to a bodily movement (pp. 71/338, 76/334). ${ }^{6}$ Thoughts, by contrast, are "timeless and unchangeable" (p. 76/343). Thoughts do not come in and out of existence and if they are true, they are so timelessly. Moreover, they are

5 The two following passages discuss explicitly only the mind-independent truth of thoughts. Their mind-independent existence is only suggested by Frege's analogies. But it is explicitly stated in passages I quote below.

${ }^{6}$ Frege has apparently no qualms about the causal efficacy of the mental and its threat to the causal closure of the physical world. 
causally efficacious, or "actual" (wirklich), only in an indirect way, in so far as they are grasped. Being causally efficacious is an external or "inessential" property of thoughts; and even if thoughts can be causally efficacious in an indirect way, they are never in turn subject to change as a result of mental or physical events (pp. 76-77/344-345).

A thought, for Frege, (a) is not the product of a mental act of thinking, and (b) is not identical to a mental act of thinking:

Now we cannot [a] regard thinking as a process which generates thoughts. It would be just as wrong to [b] identify a thought with an act of thinking, so that a thought is related to thinking as leap is to leaping [...]. [I]f thoughts [a] only came into existence as a result of thinking or $[\mathrm{b}]$ if they were constituted by thinking, then the same thought could come into existence, cease to exist, and then come into existence again, which is absurd. As I do not create a tree by looking at it or cause a pencil to come into existence by taking hold of it, neither do I generate a thought by thinking.

(Frege, 1897, p. 149/237)

Thinking a thought should not be understood on the model of building a house, where the house is the product generated by the activity of building. It should also not be understood on the model of taking a leap, where the leap simply consists in the act of leaping. ${ }^{7}$ Rather, thinking a thought should be understood on the model of grabbing a pencil: the pencil is there, independently of the act of grabbing, and you grab it. (Even better, it should be understood on the model of grabbing a stone, since the existence of artifacts such as pencils is ultimately due to actions.) As Frege goes on to say,

The metaphors that underlie the expressions we use when we speak of grasping a thought, of conceiving, laying hold of, seizing [...] put the matter in essentially the right perspective. What is grasped, taken hold of, is already there and all we do is take possession of it.

(Frege, 1897, p. 149/237)

${ }^{7}$ For Twardowski (1912), a leap is not identical to an act of leaping, but is its product. It is clear that in the passage I quoted Frege does not understand the leap example in that manner. He offers it as an analogy illustrating the view that a thought is constituted by an act of thinking, as an alternative to the view that a thought is generated by an act of thinking. 
Thus Frege explicitly rejects both act-based accounts identifying the primary truth-bearers with the products of acts of thinking and act-theoretic accounts identifying the primary truth-bearers with acts of thinking - and the rejection carries over implicitly to any account that makes the primary truth-bearers dependent on mental and linguistic acts.

The view that the primary truth-bearers are mind-independent entities goes hand in hand, in Frege, with a relational analysis of indirect speech. For Frege, "S thinks/judges/says that p" has a relational form. The that-clause refers to a thought (Frege, 1892, p. 37/160). More specifically, it functions as a "proper name". ${ }^{8}$ The thought it refers to is, accordingly, an object." Now, if the that-clause is the proper name of an object and the expression schematically represented by " $\mathrm{S}$ " is the proper name of a thinker or speaker, i.e., another object, and if the whole sentence is meant to express a thought (which is obviously the case), then the verb of the main clause can only stand, in Frege's system, for a two-place, first-level relation. And in fact, Frege describes grasping a thought in relational terms: "When [a man] grasps or thinks a thought he does not create it but only comes to stand in a certain relation to what already existed" (1918, p. 70/337, n. E; see also p. 76/344).

It is easy to see how Frege's theory accounts for our three platitudes. A person can think or say the same thing on different occasions (Repeatability), and different people can think or say the same thing (Shareability), for the same reason for which a person can grab the same stone on different occasions, and different people can grab the same stone. Moreover, what we say or think may be true or false independently of the fact that anybody has ever thought or said it (Objectivity), for the same reason for which a stone can weight $1 \mathrm{~kg}$ independently of the fact that anybody has ever grabbed it.

8 "The subordinate clause [in indirect speech] could be regarded as a noun, indeed one could say: as a proper name [Eigenname] of that thought [...] which is represented in the context of the sentence structure" (Frege, 1892, p. 39/162).

9 For Frege, as is well known, a proper name (Eigenname) is any expression, simple or complex, which refers to an object, "this word taken in the widest range", so as not to be restricted to what belongs to the temporal and causal order, let alone to what is material and spatial (Frege, 1892, p. 27/153). 


\section{A questionable reading of Frege?}

In taking at face value Frege's talk of the "third realm", I disagree with some of the claims of anti-metaphysical readers of Frege. ${ }^{10}$ There are in fact different anti-metaphysical readings of Frege and different points of disagreement between each anti-metaphysical reading and its opponents. This is not the place to try to resolve a complex debate that has gone on for more than three decades. I will only add some remarks that help to locate the interpretation I endorse in the extant debate and provide some reasons for preferring it to one of the most relevant alternatives.

A significant part of the disagreement between the anti-metaphysical reading proposed by Joan Weiner $(1990,1995 \mathrm{a}, 1995 \mathrm{~b})$ and the Platonist reading proposed by Tyler Burge (1992) concerns the issue of whether thoughts, for Frege, are essentially capable of being grasped and expressed. Weiner agrees with Burge that thoughts, for Frege, are independent of our actual mental or linguistic performances, but maintains, contra Burge, that they are not independent of our possible mental or linguistic performances (1995a, p. 591; 1995b, pp. 368-72). In this sense, she insists, they are minddependent. The interpretation I presented in the previous section leaves open the question of whether Fregean thoughts are mind-dependent in this sense. My contention is that they are independent of our actual mental or linguistic performances. This is the sort of mind-independence that I am interested to discuss in this paper and with respect to which I want to draw a contrast between Frege and the Tractatus.

There is, however, a substantive disagreement between the interpretation I presented and the deflationist brand of anti-metaphysical reading advocated by Thomas Ricketts (1986). On Ricketts' view, the whole talk of thoughts as objects inhabiting a third realm is only a way of "systematically redescribing" our practicing of asserting and inferring (1986, pp. 72, 92). In my terms, such talk is not meant to express a philosophical account of the sort of platitudes with which I started, but a way of restating those platitudes. For example, the claim that thoughts are objects existing independently of the fact that anybody grasps them is just a way of saying that

${ }_{10}$ See especially Ricketts (1986), Weiner (1990, 1995a, 1995b), Carl (1994, pp. 76-92 and 194-201), Rousse (2015). For a classic defense of a thoroughly metaphysical reading of Frege, see Burge (1992). 
different people can think the same thing, and that something can be true even if nobody thinks it. Frege's claims about thoughts and the third realm are simply meant to restate the data, not to explain them.

What I find problematic in this reading is that it does not specify what is supposed to be achieved by Frege's "redescriptions". Ricketts speaks of "systematic" (1986, pp. 72, 92) or "structured" (p. 73) redescriptions. But nowhere does he explain what the relevant sort of systematicity is supposed to be. On his reading, Frege's redescriptions cannot be "systematic" in the sense that they offer a unified explanation of the relevant platitudes based on a relational analysis of indirect speech and an ontology of thoughts as mind-independent entities. In which sense, then, are they "systematic"? What kind of systematicity do we gain, for instance, in restating "Different people can state the same thing" as "Different people can stand in a relation of 'grasping' to the same atemporal, mind-independent object"? The only systematicity I can discern in such redescriptions, on the assumption that they are not meant to provide any sort of explanation, is that they are systematically misleading, since they suggest precisely the sort of explanation that, according to Ricketts, Frege did not really endorse.

None of this is to deny that there are several aspects of Frege's philosophy - rightly emphasized by Ricketts and other anti-metaphysical readers - that are in tension with the view I ascribed to him in the previous section. These include, arguably, Frege's claim that the distinctive character of his logic lies in the fact that he "start[s] from judgments and their contents, and not from concepts" (Frege, 1880/81, p. ,17/16; cf. Ricketts, 1986, p. 67); his reluctance to call truth a property (Frege, 1918, p. 62/329; cf. Ricketts, 1986, p. 79); the idea that "what logic is really concerned with is not contained in the word 'true' at all but in the assertoric force with which a sentence is uttered" (Frege, 1915, p. 272/323; cf. Ricketts, 1986, p. 84); and the definition of sense in terms of linguistic expressions and their reference (Frege, 1893, §32; cf. Dummett, 1986). What I deny is that the passages I discussed in the previous section can be reconciled with the perspective that emerges from these other regions of Frege's philosophy. ${ }^{11}$

Now I am going to argue that the Tractatus rejects the major tenets of the theory I ascribed to Frege in the previous section. For the Tractatus,

11 The idea that this is the locus of a genuine tension in Frege's philosophy is defended, for instance, in Dummett (1986). 
(i) the primary truth-bearers are not mind-independent, (ii) can be sensibly perceptible, (iii) are not objects, and (iv) indirect speech is not liable to a relational analysis.

\section{The Tractatus on pictures, thoughts, and propositions}

The Tractatus ascribes truth and falsity to three sorts of items: "pictures", "thoughts", and "propositions". Here are some representative passages: ${ }^{12}$

2.21 The picture $[$ Bild $]$ agrees with reality or not; it is right or wrong, true or false.

3.01 The totality of true thoughts [Gedanken] is a picture of the world.

4.022 The proposition [Satz] [...] shows how things stand, if it is true.

The Tractatus speaks of truth also in two other contexts: in connection with solipsism ("This [...] raises the question, to which extent solipsism is a truth," 5.62), and in relation to the views apparently expressed in the Tractatus itself ("The truth of the thoughts expressed here seems to me unassailable and definitive," Preface). These cases, however, raise special problems and I will ignore them in what follows. Given what the Tractatus says about its own propositions (namely, that they are nonsensical, 6.54) and about philosophy (namely, that "it is not a theory, but an activity", and that "the result of philosophy is not a number of "philosophical propositions", 4.112), it is reasonably clear that the term "truth" is used in these contexts in a special sense, which differs from the sense it carries elsewhere in the book.

So let's focus on pictures, thoughts, and propositions. How are they related? This is a very controversial exegetical issue. In fact, it is not obvious that there is room for any coherent account of the matter that does not do some violence to (or at least some massaging of) the relevant texts. I will begin with some points that I take to be uncontroversial.

It is clear that thoughts and propositions are pictures:

3 The logical picture of facts is the thought.

4.01 The proposition is a picture of reality.

12 I generally follow the Ogden-Ramsey translation, with some unmarked modifications. 
Thoughts and propositions fall, therefore, within the scope of the socalled "Picture Theory". It is also reasonably clear that the Picture Theory includes the following tenets. A Tractarian picture consists in the fact that a certain number of elements stand to one another in a certain way. Each element of the picture stands for, or "deputizes", an element of reality. The fact that the elements of the picture stand to one another in a certain way represents the fact that the correlative elements of reality stand in that way. If they do indeed so stand, the picture is true; otherwise it is false. Finally, the picture and what it pictures share the same form, which means that their elements have the same combinatorial possibilities (2.1-2.225).

Things get more complicated when we try to be more specific about the relation between pictures, thoughts, and proposition. With regard to the relation between pictures and thoughts, there are two live options. One option is to maintain that pictures and thoughts are co-extensional, as suggested by the following passages:

3 The logical picture of facts is the thought.

2.182 Every picture is also a logical picture.

(On the other hand, for example, not every picture is spatial.)

If a thought is a logical picture, and every picture is (inter alia) a logical picture, then - it would seem - every picture is a thought. And of course, since a thought is a logical picture, every thought is a picture. A thought, on this reading, would be a picture considered only as a logical picture, in abstraction from the fact that it might also be a more specific sort of picture, such as a spatial or temporal picture. Thus spatial or temporal pictures, which represents reality in virtue of sharing with it not only logical form but also spatial or temporal form, count as thoughts. ${ }^{13}$

The other option is to hold that thoughts are only-logical pictures, namely pictures that share with what they represent nothing more than logical form. On this reading, thoughts are a proper subset of pictures. There are pictures, such as spatial or temporal pictures, that are not thoughts. ${ }^{14}$

It seems to me that this second reading makes best overall sense of the text. A piece of textual evidence in its support is the following. The Tractatus

13 For a reading of this sort, see Frascolla (2007), chapter 2.

${ }_{14}$ Anscombe (2011, p. 172) proposes a similar reading of the relation between pictures and propositions, which are also said to be "logical pictures" (4.03). 
says that "the logical picture can depict the world" (2.19), where "the world is everything that is the case" (1). It also says, in accordance with its definition of a thought as a logical picture, that thoughts can depict the world: "The totality of true thoughts is a picture of the world" (3.01). But for the Tractatus, it is not the case that any sort of picture can depict the world. For example, a spatial picture, qua spatial picture, can only depict a spatial situation: it cannot depict, say, a temporal or chromatic situation (2.171). It cannot do so because it does not share the form of a temporal or chromatic situation. The only form that belongs to everything that is the case is logical form (2.18). Thus the only sort of picture that can depict everything that is the case is a picture that represents simply in virtue of its logical form. It is, in other words, an only-logical picture. So "logical pictures" and thus "thoughts" are only-logical pictures.

This conclusion fits well with the fact that logical pictures are ostensibly introduced as a special case of pictures:

2.181 If the form of representation is the logical form, then the picture is called a logical picture.

If every picture were a logical picture, this definition would make no sense: there would be no condition that a picture would have to satisfy in order to be "called a logical picture". Admittedly, our conclusion does not fit well with the immediately following remark, which has already been quoted:

2.182 Every picture is also a logical picture.

If a logical picture were here an only-logical picture, this statement would be self-contradictory. The "also" and the "only" would clash with each other. A spatial picture, for example, can't be also an only-logical picture, for to say that it is an only-logical picture is precisely to say that it is nothing more than that. My suggestion is that the Tractatus is in fact working, even at such a minimal textual distance, with two notions of "logical picture": an inclusive notion, which applies to all pictures, and a narrow notion, which applies only to only-logical pictures. Thoughts, which can depict the world, are logical pictures in the narrow sense.

We can now move on to the question of the relation between thoughts and propositions, which is even more complicated. One the one hand, it seems that propositions and thoughts are supposed to be the very same thing: 
4 The thought is the significant proposition.

The Tractatus speaks here of "significant propositions" instead of propositions tout court; but on many occasions, it clearly uses the two terms interchangeably - for instance, when it says that "a proposition shows its sense" (4.002). So the Tractatus appears to identify thoughts and propositions. But on the other hand, the identity of propositions and thoughts seems flatly incompatible with what Wittgenstein writes in a famous 1919 letter to Russell. Russell had sent a letter to Wittgenstein asking for several clarifications about the Tractatus. He noticed that, for the Tractatus, "The thought is the significant proposition" (4) and "The totality of propositions is the language" (4.001). So he asked, "Does a Gedanke consist of words?" (Wittgenstein, 2008, p. 96). To which Wittgenstein replied:

No! But of psychical constituents that have the same sort of relation to reality as words. What those constituents are I don't know.

(Wittgenstein, 2008, p. 99)

It is beyond doubt that a proposition, for the Tractatus, consists of words or more generally, of linguistic items. Not only propositions are said to be part of language, as Russell notices, but a proposition is said to be a "propositional sign", such as a "sound or written sign" in "its projective relation to the word" $(3.11,3.12)$. Moreover, the elements of completely analyzed propositions are said to be "simple signs" or "names" (3.202). The passage from the letter to Russell appears therefore to imply that thoughts and propositions form disjoint classes. Both propositions and thoughts are pictures, but thoughts consist of psychic elements, whereas propositions consist of linguistic elements. Thoughts are mental pictures, whereas propositions are linguistic pictures.

The idea that thoughts and propositions are different kinds of pictures leads to a particular construal of another Tractarian characterization of their relation. For the Tractatus, a proposition is the sensibly perceptible expression of a thought:

3.1 In the proposition the thought is expressed perceptibly through the senses. 
If thoughts and propositions are distinct items, then to be the "expression" of a thought is a matter of being an item that is correlated to another item. Behind every proposition there is a thought, which is expressed by the proposition. But now it is hard to see why this should be the case unless what is doing the real representational job is the thought, i.e., a mental picture, and the proposition is a picture only in a vicarious, derivative way. The intentionality of language piggybacks on the intentionality of the mental.

This very familiar, Lockean view has sometimes been ascribed to the Tractatus. ${ }^{15}$ But there is good reason to resist such a reading. The Tractatus contains no explicit distinction between first-rate and second-rate pictures. Thoughts and propositions are simply described as (logical) pictures, and have as such equal status. Given their shared pictorial nature, it is unclear why a mental picture should be able to do something that a linguistic picture cannot do. In fact, if the early Wittgenstein is committed to any priority between language and thought, he seems to give priority - even though only of a heuristic sort - to linguistic pictures. As emerges in the letter to Russell we are discussing, Wittgenstein conceives of mental pictures on the model of linguistic pictures: "[A Gedanke consists] of psychical constituents that have the same sort of relation to reality as words." That is, a thought consists of psychical elements that play the same role of words. The point is conveyed even more explicitly in a 1916 entry of the pre-Tractarian Notebooks:

Now it is becoming clear why I thought that thinking and speaking were the same. For thinking is really a kind of language [eine Art Sprache]. For a thought [...] just is a kind of proposition [eine Art Satz].

(Wittgenstein, 1979, p. 82, modified translation)

This does not mean that a thought is a kind of proposition in the way German and English propositions are kinds of propositions, but in the sense that it is like a proposition (a proposition of sorts, one might say) in all the essential respects, i.e., in all the respects that determine its representational properties. ${ }^{16}$

15 See e.g., Kenny (1981) and Malcolm (1986), pp. 63-82.

16 These considerations are not meant to suffice to refute the priority-of-thought reading of the Tractatus, but only to cast doubts on it. The issue is at the center of a long dispute between "mentalist" and "non-mentalist" readings of the Tractatus. For additional 
If there isn't necessarily a mental picture behind every linguistic picture, we need a different reading of the claim that propositions express thoughts - one that does not construe the idea of expression as a correlation between something inner and something outer. I suggest that Ramsey points us in the right direction:

As to the relation between a proposition and a thought Mr Wittgenstein is rather obscure; but I think his meaning is that a thought is a type whose tokens have in common a certain sense, and include the tokens of the corresponding proposition, but include also other non-verbal tokens; these, however, are not relevantly different from the verbal ones, so that it is sufficient to consider the latter.

(Ramsey, 1923, p. 274)

The idea I want to take from this passage is that propositions are thoughts. They are thoughts taking a linguistic, sensibly perceptible form. Not all thoughts must take such a form: some may take a psychic, non-linguistic form. A proposition "expresses" a thought in the sense that it embodies or instantiates it, where the instantiation is sensibly perceptible. ${ }^{17}$ What all the expressions of the same thought have in common, be they mental or linguistic, is that they are only-logical pictures with the same sense. ${ }^{18}$

This leaves us with two difficulties. If a thought may take the form of a proposition, why does Wittgenstein deny, in the letter to Russell, that it consists of words? What it should have said is that it may or may not consist of words. And if a thought does not have to take the form of a proposition, why does the Tractatus say that "[t]he thought is the significant proposition" (4)? Shouldn't he have said that some thoughts are significant propositions?

arguments against the priority-of-thought reading, see Winch (1987), pp. 3-17, and McGuinness (2002), pp. 82-102.

17 One may object that "to express" simply does not mean "to instantiate (in a sensibly perceptible manner)". It means to "press something out", either literally or metaphorically, and in either case there must be something inner and something outer. But consider this use of the term: "This painting is a good expression of impressionist art". It is a good expression of impressionist art in the sense that it is a good instance of it. I suggest that the Tractarian notion of expression should be construed along similar lines.

18 Frascolla (2011, chapter 2) proposes a similar reading, but goes further than I do in maintaining that the tokens of a thought include all the pictures that express the same sense, whether or not they are only-logical pictures. 
I propose to solve the first difficulty by holding that the early Wittgenstein uses the term "thought" in (at least) two senses. When he says in the Tractatus that a proposition expresses a thought, the term is used in a wide sense that applies to all only-logical pictures. By contrast, in the letter to Russell the term is used in a narrow sense that applies only to mental only-logical pictures. With regard to the second difficulty, I suggest that "The thought is the significant proposition" should be read as: "The thought (= the only-logical picture) is, in the clearest case, the significant proposition". Not all thoughts consist of words; but what renders any thought an only-logical picture of reality is what can be seen, and can be seen most clearly, in propositions. That is why Wittgenstein feels entitled, in the rest of the Tractatus, to focus only on propositions.

Summing up, I have argued that the primary truth-bearers, for the Tractatus, are pictures. Thoughts are a proper subset of pictures, and propositions are in turn a proper subset of thoughts. A thought is an only-logical picture, and a proposition is a thought taking a linguistic form. There are pictures that are not thoughts, such as spatial or chromatic pictures; and there are thoughts that are not propositions, such as mental only-logical pictures.

So far I have brought out two differences between the Tractatus and Frege. First, for the Tractatus the primary truth-bearers can be (though need not be) sensibly perceptible: they can consist of spoken or written words. Secondly, the primary truth-bearers are not objects, but facts ("The picture is a fact", 2.141). It is a central doctrine of the Tractatus, and a central criticism of Frege, that objects and facts differ categorically. Objects can only be named (3.221), and facts can only be described (3.114). The distinction is as deep and uncompromising as Frege's own distinction between objects and concepts. For Frege, there is no such thing as using a proper name to refer to a concept: the only way to refer to a concept is to use an expression predicatively. Strictly speaking, the term "refer" is itself categorically ambiguous when applied to proper names and concept-expressions: in the sense in which we may refer to objects, we may not refer to concepts. Similarly, for the Tractatus, there is no such thing as using a name to refer to a fact. The only way to think or speak of a fact is to describe it by means of another fact, i.e., to picture it. In the sense in which we may think or speak of objects, we may not think or speak of facts.

This is enough to show that the Tractatus cannot accept Frege's relational analysis of indirect speech. And in fact, as we are going to see 
below, it explicitly rejects any such analysis. But before we get to that point, I want to show that the primary truth-bearers, for the Tractatus, are not mind-independent.

\section{Pictures as facts-in-use}

We saw that a Tractarian picture is a fact. But it is not just a fact, for there are many facts that don't represent anything. A picture is a fact together with the "representing relation" (2.1513), i.e., the coordination of the elements of the picture with the elements of the possible situation it represents (2.1514). When the Tractatus introduces the notion of a proposition, it makes clear that standing in a representing relation to reality is a matter of being used in a certain way. The Tractatus distinguishes between the "proposition" and the "propositional sign". A propositional sign is a fact: the fact that its elements, namely linguistic signs, stand to one another in a certain way (3.11-3.14); and a proposition is an "applied" propositional sign (3.5-4), that is a sign that is "used" as a projection of a possible situation (3.11). It seems clear that what is said about propositions is meant to apply to pictures more generally. A picture is a fact that is used as a projection of a possible situation. If this is correct, Tractarian truth-bearers essentially involve use, and thus the act of some thinker or speaker. At the same time, they essentially involve an instrument of representation, namely a fact (either mental or linguistic) that is put to a picturing use.

This conclusion is supported by at least two other pieces of textual evidence. First, the notion of a picture is introduced in the Tractatus with reference to picturing agents:

2.1 We make to ourselves pictures of facts.

A picture is something we make. There is no picture without an act and someone performing the act. Secondly, when the Tractatus moves on to consider the case of propositions, it draws a distinction between "signs" and "symbols". A symbol is "everything - essential for the sense of a proposition - that propositions may have in common with one another" (3.31), and propositions are limiting cases of symbols (3.313). A sign is "what is sensibly perceptible in the symbol" (3.2). A crucial feature of the distinction 
is that "the same sign [...] can be common to different symbols": the sign "is", for example, may symbolize now as the copula, now as the sign of existence, now as the sign of identity (3.321-3.323). In order to "recognize the symbol in the sign", we are told, "we must consider its significant use" (3.326). For instance, in order to recognize which symbol the sign "is" is on a particular occasion, we need to look at how it is used, on that occasion, to contribute to the expression of a propositional sense. So symbols, which include propositions, are signs-in-use.

Now, if the bearers of truth and falsity are not mind-independent objects, what is it to think or say that something is the case? And what is it to report, in speech or thought, that someone thinks or says that something is case? In other words, how should we analyze propositions of the form "S thinks/says that p"? The Tractarian discussion of this topic (5.541-5.5422) is almost oracular in its brevity and has challenged generations of commentators:

5.542 But it is clear that "A believes that p", "A thinks p", "A says p" are of the form " "p" says p": and here we have no co-ordination of a fact and an object, but a co-ordination of facts by means of a co-ordination of their objects.

Whatever the Tractarian theory of indirect speech amounts to, one thing is clear: it rejects the relational analysis. Wittgenstein states his target in the immediately preceding remark:

$5.541[\mathrm{I}] \mathrm{n}$ certain propositional forms of psychology, like "A thinks, that $p$ is the case", or "A thinks p", etc. [...] it appears superficially as if the proposition $\mathrm{p}$ stood to the object $\mathrm{A}$ in a kind of relation (And in modern epistemology [Russell, Moore, etc.] those propositions have been conceived in this way.)

Wittgenstein mentions Russell and Moore, but if what I argued above is correct, he could have mentioned Frege as well. Propositions of the superficial form "A thinks/says that p" do not assert that an object, the thinking or speaking subject, stands in relation to another object, the proposition that $\mathrm{p}$. And they do not even assert that the thinking or judging subject, construed as an object, stands in relation to a proposition, construed as a fact. Rather, they "coordinate facts". 
But what could that mean? If what has sense, and is true or false, is a fact-in-use, thinking or saying that $p$ should consist in using a fact in a certain way. By the same token, reporting what someone else has thought or said should consist in describing a certain fact (or at least its general structure, if we are not interested in reporting the exact words or "psychic constituents" that were used), and then specifying the way it was used. The question is how such an accomplishment could be thought to have the form " $p$ ' says that p". Answering this question in detail, and doing so in a manner that fits what else is going in the Tractatus, would take heavyweight exegetical work. Here I only want to suggest that it might not be impossible to tell a plausible story along the following lines: The " $p$ "” in Wittgenstein's formula stands for the description of a fact, and the "says that p" stands for a specification of how the fact has been used. Of course, a great deal turns on how such a "specification" is to be construed, since it can't be anything like the ascription of a property to an object. ${ }^{19}$

\section{Back to the three platitudes}

Frege would likely discard the Tractarian account of truth-bearers on the ground that it can't vindicate the three platitudes from which I started. But is it so?

Let's begin with Repeatability and Shareability. Some contemporary advocates of the act-theoretic approach, such as Scott Soames and Peter Hanks, vindicate these platitudes by means of a distinction between acttypes and act-tokens. To think or say the same thing is a matter of producing tokens of the same act-type. I suggest that the Tractatus can adopt the same strategy. A person can think or say the same thing on different occasions, and different people can think or say the same thing, for the same reason for which a person can perform the same action on different occasions, and different people can perform the same action. Actions are obviously agentdependent: there is no action without an agent. Just as Fregean “ideas" don't

19 For the idea that the Tractatus adopts the convention of using " $p$ "” as an abbreviation of the description of a propositional sign-fact (so that " $\mathrm{aRb}$ " " is shorthand for "that ' $a$ ' stands to the left and ' $b$ ' to the right of 'R'"), see Diamond 2012. For resources to think about how the relevant sort specification should be construed, see Bronzo (2019). 
go around the world without somebody who "has" them, so actions don't go around the world without somebody who "does" them. But this does not mean that actions cannot be repeated and performed by different people. I can now take a leap, and I can do it again, and you can do the same thing. This does not mean that there is an agent-independent object out there, "the leap", to which we both stand in a relation of "taking". To perform the same action is a matter of tokening the same action-type. Similarly, the Tractatus can maintain that thinking or saying the same thing is a matter of using appropriate facts in the same sort of way. The facts must have, in their fully analyzed form, the same "logical multiplicity" (4.04), that is the same number of simple elements with the same combinatorial possibilities; and such facts must be put to the same picturing use, that is, projected onto the same possible situation. If we take appropriate facts and use them in the appropriate sort of way, we think or say the same thing - just as we can do the same thing, say hammering, if we take an appropriate tool and use it in the appropriate sort of way.

Now, what about the platitude I called Objectivity? If what is true or false are facts-in-use, how is it possible that it was true, say, that 2 plus 2 equals 4 well before anybody existed to use any fact at all? Some contemporary act-theoretic accounts of truth-bearers, such as Peter Hanks' (2015, p. 27), seek to vindicate this platitude by positing act-types that exist and are true or false independently of the actual existence of any of their tokens. It is questionable, however, that this reification of act-types is compatible with the claim that the primary truth-bearers are concrete, historical acts, and the proposal threatens to collapse into a version of the view that the primary truth-bearers are mind-independent entities (Reiland, 2017). Moreover, the idea that reified act-types are true or false is incompatible with the Tractarian insistence that only facts, and not objects, can be true or false. Finally, once we have introduced reified act-types as bearers of truth and falsity, it is hard to resist a relational analysis of indirect speech. If thinking/saying that $p$ is tokening an act-type, and the act-type is a self-standing entity that exists independently of its actual tokens, then it seems that "tokening" an act-type is a matter of standing in some sort of relation to an object. This is in fact Hanks' account $(2015$, p. 28). But as we have seen, it is not an account that the Tractatus would accept.

There is another strategy that is open to the Tractatus for vindicating Objectivity. The Tractatus may adopt a deflationist analysis of the occurrence 
of the truth-predicate in sentences of the form "It is true that p". On this view, the sentence "It is true that p" says the same as "p". But if this is correct, when we say that it was true that 2 plus 2 equals 4 before anybody thought or said it, we just mean that $2+2$ equaled 4 before anybody thought or said it. And this, of course, does not require the existence of any thinking or speaking subject. ${ }^{20}$

\section{References}

Anscombe, G.E.M. (2011). The Simplicity of the Tractatus. In: M. Geach, L. Gormally (eds.), From Plato to Wittgenstein (pp. 171-80). Exeter: Imprint Academic.

Bell, D. (1987). Thoughts. Notre Dame Journal of Formal Logic, 28 (1), 36-50.

Bourge, T. (1992). Frege on Knowing the Third Realm. Reprinted in T. Burge (2005), Truth, Thought, Reason. Essays on Frege (pp. 299-316). Oxford: Oxford University Press.

Bronzo, S. (2019). Propositional Complexity and the Frege-Geach Point. Synthese. DOI: $10.1007 / \mathrm{s} 11229-019-02270-1$.

Carl, W. (1994). Frege's Theory of Sense and Reference: Its Origins and Scope. New York: Cambridge University Press.

Diamond, C. (2012). What Can You Do with the General Propositional Form? In: J.L. Zalabardo (ed.), Wittgenstein's Early Philosophy (pp. 151-194). Oxford: Oxford University Press.

Dummett, M. (1986). Frege's Myth of the Third Realm. Reprinted in M. Dummett (1996), Frege and Other Philosophers (pp. 249-62). Oxford: Oxford University Press.

Frascolla, P. (2007). Understanding Wittgenstein's "Tractatus". Abingdon: Routledge.

Frege, G. (1880/81). Booles rechnende Logik un die Begriffsschrift. In: G. Frege, Nachgelassene Schriften (1969). Eds. H. Hermes, F. Kambartel, F. Kaulbach (pp. 9-52). Hamburg: Felix Meiner. Translated as “Boole's Logical Calculus

${ }^{20}$ For an act-based account that adopts this strategy for vindicating Objectivity, see Jubien (2001), pp. 59-60. Evidence that the early Wittgenstein might be sympathetic to this solution can be found in the Notebooks: "p' is true, says nothing else but p" (Wittgenstein, 1979, p. 9). See also the arguments for an "operational" reading of the Tractarian account of truth-expressions in Gomułka \& Wawrzyniak (2013). 
and the Concept Script" in G. Frege (1979), Posthumous Writings (pp. 9-52). Oxford: Blackwell.

Frege, G. (1892). Über Sinn und Bedeutung. Zeitschrift für Philosophie und philosophische Kritik, 100, 25-50. Translated as "On Sinn and Bedeutung" in Frege (1997), The Frege Reader (pp. 151-71). Ed. M. Beaney. Oxford: Blackwell.

Frege, G. (1893). Grundgesetze der Aritmetik. Band 1. Jena: Verlag Hermann Pohle. Selections translated in Frege (1997), The Frege Reader (pp. 194-223). Ed. M. Beaney. Oxford: Blackwell.

Frege, G. (1897). Logik. In: G. Frege, Nachgelassene Schriften (1969). Eds. H. Hermes, F. Kambartel, F. Kaulbach (pp. 137-63). Hamburg: Felix Meiner. Partially translated as "Logic" in Frege (1997), The Frege Reader (pp. 227-250). Ed. M. Beaney. Oxford: Blackwell.

Frege, G. (1915). Meine grundlegenden logischen Einsichten. In: G. Frege, Nachgelassene Schriften (1969). Eds. H. Hermes, F. Kambartel, F. Kaulbach (pp. 271-272). Hamburg: Felix Meiner. Translated as "My Basic Logical Insights" in Frege (1997), The Frege Reader (pp. 322-324). Ed. M. Beaney. Oxford: Blackwell.

Frege, G. (1918). Der Gedanke. Eine Logische Untersuchung. Beiträge zur Philosophie des deutschen Idealismus, I, 58-77. Translated as "Thought" in Frege (1997), The Frege Reader (pp. 325-345). Ed. M. Beaney. Oxford: Blackwell.

Frege, G. (1997). The Frege Reader. Ed. M. Beaney. Oxford: Blackwell.

Gomułka, J., Wawrzyniak, J. (2013). Some Arguments for an Operational Reading of Truth Expressions. Analiza i Egzystencja, 24, 61-86.

Hanks, P. (2007). The Content-Force Distinction. Philosophical Studies, 134 (2), $141-164$.

Hanks, P. (2011). Structured Propositions as Types. Mind, 120 (477), 11-52.

Hanks, P. (2015). Propositional Content. Oxford: Oxford University Press.

Jubien, M. (2001). Propositions and the Objects of Thought. Philosophical Studies, 104 (1), 47-62.

Kenny, A. (1981). Wittgenstein's Early Philosophy of Mind. In: I. Block (ed.), Perspectives on the Philosophy of Wittgenstein (pp. 140-7). Oxford: Blackwell.

Malcolm, N. (1986). Nothing is Hidden: Wittgenstein's Criticism of His Early Thought. Oxford: Blackwell.

McGuinness, B. (2002). Approaches to Wittgenstein: Collected Papers. London: Routledge. 
Moltmann, F. (2003). Propositional Attitudes without Propositions. Synthese, 135, $70-118$.

Moltmann, F. (2014). Propositions, Attitudinal Objects, and the Distinction between Actions and Products. Canadian Journal of Philosophy, 43, 679-701.

Moltmann, F. (2017). Cognitive Products and the Semantics of Attitudes Verbs and Deontic Modals. In: F. Moltmann. M. Textor (eds.), Act-Based Conceptions of Propositional Content. Historical and Contemporary Perspectives (pp. 254-89). Oxford: Oxford University Press.

Moltmann, F, Textor, M. (eds.) (2017). Act-Based Conceptions of Propositional Content. Historical and Contemporary Perspectives. Oxford: Oxford University Press.

Ramsey, F. (1923). Critical Notice of Wittgenstein's “Tractatus". Mind, 32, 465-78.

Reiland, I. (2017). Review of Peter Hanks's “Propositional Content”. Philosophical Review, 126, 132-6.

Ricketts, T. (1986). Objectivity and Objecthood: Frege's Metaphysics of Judgment. In: L. Haaparanta, J. Hintikka (eds.), Frege Synthesized (pp. 65-95). Dordrecht: Reidel.

Rousse, B.S. (2015). Demythologizing the Third Realm: Frege on Grasping Thoughts. Journal for the History of Analytic Philosophy, 3 (1), 1-14.

Ryle, G. (1930). Are There Propositions? Reprinted in G. Ryle (2009), Collected Essays 1929-1968: Collected Papers Volume 2 (pp. 13-40). Abingdon: Routledge.

Soames, S. (2010a). What Is Meaning? Princeton: Princeton University Press.

Soames, S. (2010b). Philosophy of Language. Princeton: Princeton University Press.

Soames, S. (2015). Rethinking Language, Mind, and Meaning. Princeton: Princeton University Press.

Soames, S. (2016). Propositions, the "Tractatus", and the "Single Great Problem of Philosophy". Crítica: Revista Hispanoamericana de Filosofia, 48 (143), $3-19$.

Twardowski, K. (1912). Actions and Products: Some Remarks from the Borderline of Psychology, Grammar, and Logic. Reprinted in F. Moltmann. M. Textor (eds.) (2017), Act-Based Conceptions of Propositional Content. Historical and Contemporary Perspectives (pp. 78-104). Oxford: Oxford University Press.

Weiner, J. (1990). Frege in Perspective. Ithaca: Cornell University Press. 
Weiner, J. (1995a). Burge's Literal Interpretation of Frege. Mind, 104 (415), 585-97.

Weiner, J. (1995b). Realism bei Frege. Synthese, 102 (3), 363-82.

Winch, P. (1987). Trying to Make Sense. Oxford: Blackwell.

Wittgenstein, L. (1922). Tractatus Logico-Philosophicus. Trans. C.K. Ogden, F. Ramsey. London: Routledge and Kegan Paul.

Wittgenstein, L. (1979). Notebooks 1914-1916. 2nd edition. Eds. G.H. von Wright, G.E.M. Anscombe. Trans. G.E.M. Anscombe. Oxford: Blackwell.

Wittgenstein, L. (2008). Wittgenstein in Cambridge. Letters and Documents 1911-1951. Ed. B. McGuinness. Oxford: Blackwell.

\begin{abstract}
This paper argues that the Tractatus breaks deeply with Frege's account of truthbearers as mind-independent entities, and is closer to the act-theoretic approach recently defended, for example, by Scott Soames and Peter Hanks. For the Tractatus, the primary truth-bearers are facts-in-use, which essentially involve acts, as well as facts functioning as instruments of representation. The Tractarian account, it is further argued, can vindicate three platitudes that constitute the main motivation of Frege's approach.
\end{abstract}

